Copyright (c) 2006 Associação Brasileira de Pesquisadores em Jornalismo / SBPJor

\section{MEDIA AND RELIGION IN BRAZIL}

\author{
The rise of TV Record and UCKG \\ and their attempts at globalization
}

RAUL REIS

California State University, USA
ABSTRACT

KEY-WORDS
The Universal Church of the Kingdom of God (UCKG), a neoPentecostal religious group originally from Brazil, has attracted a great deal of attention since it was founded by Pastor Edir Macedo in 1977. Part of that attention is due to the group's and its leaders' non-traditional religious practices, which include syncretic versions of Christian Pentecostal, shamanistic, and Afro-Brazilian Umbandan rituals. A great deal of scrutiny, however, centers on the fact that since the UCKG purchased TV Record in the early 1990s, the group has become a major player in the very desirable and profitable Brazilian broadcasting market. This paper examines the rise of UCKG as a major media player in Brazil, and also sheds some light into the Church's attempts at globalizing (or at least expanding) its television and radio holdings to other countries and regions.

Organized religion and mass media have been uneasy bedfellows ever since the printing press was invented. From Martin Luther's Theses and other early religious pamphlets and newspapers, to the current electronic bulletin boards and chat rooms, different religious denominations have relied heavily on the written or broadcast word to spread their message.

That resulting relationship between religion and the media has been closely scrutinized by political and social institutions, in part due to Western democracies' tradition of keeping Church and state separate, but also due to the assumed charitable or non-profit-making status of most religious groups-and the assumption that most mass media organizations are, in fact, profit-making enterprises. 
The Universal Church of the Kingdom of God (UCKG), a neo-Pentecostal religious group originally from Brazil, has attracted a great deal of attention and scrutiny since it was founded by Pastor Edir Macedo in 1977 (SERBIN, 1996). Part of that attention is due to the group's and its leaders' nontraditional religious practices, which include syncretistic versions of Christian Pentecostal, shamanistic, and Afro-Brazilian Umbandan rituals (SIMÕES, 1997). A great deal of the attention, however, centers on the fact that since the UCKG purchased TV Record, a then-ailing regional broadcasting network, in the early 1990s, the group has become a major player in the very desirable and profitable Brazilian broadcasting market.

This paper examines the rise of the UCKG as a major media player in Brazil, and also sheds some light on the Church's attempts to globalize (or at least expand) its television and radio holdings to other countries and regions.

\section{TV Record's History}

TV Record has a long and notable history. The second broadcasting network in Brazil, its first station was founded in 1953, a mere three years after television was introduced in the country. As early as 1954, TV Record was already challenging the then-leader TV Tupi, with emphasis on areas such as journalism, sports and musicals. In a few years, TV Record went from a local, São Paulo-based independent station to a national network, with sister stations in Rio de Janeiro (TV Rio), and affiliates in other major Brazilian cities.

TV Record's 1960s music programs and events are legendary. From the mid-1960s on, the network's shows and music festivals launched the careers of virtually every new Brazilian singer and songwriter. Poor management and financial difficulties, coupled with competition from new stations and networks, caused the decline of TV Record and its affiliates in the late 1970s and 1980s. The network tried to reinvent itself in the mid-1980s by investing in serious journalism and attracting many top-notch newscasters. However, its efforts were not enough to attract a sizable audience and TV Record, again reduced to a local, São Paulobased network with scattered affiliates throughout that state, seemed to be going the way of the already defunct TV Tupi.

In 1990 (THE ECONOMIST, 1995; EMERGING MARKETS REPORTS, 1995; ROCHA, 2001), just when TV Record's future looked the most uncertain, the network was bought by the Universal Church of the Kingdom of God (UCKG), headed by self-appointed Bishop Edir Macedo 
for a reported US\$ 45 million (EMERGING MARKETS REPORTS, 1995). In a few years, TV Record went again from a regional to a national network, with sister stations and affiliates throughout Brazil and the third largest overall audience in the country, after Rede Globo and SBT. How exactly did that happen?

It is impossible to understand that transformation without looking at the UCKG itself, since the Church provided the financial means, the religious-ideological backbone, and the built-in audience that rescued Record from its death throes and turned it into the third largest Brazilian TV network.

\section{Pentecostalism as a Religious Phenomenon}

Pentecostalism has been identified as a particular type of "Protestant fervor" or enthusiasm that places great emphasis on the baptism in the Holy Spirit as an anointing of special powers or gifts, such as glossolalia, commonly known as the power of "speaking in tongues" (UNIVERSITY OF VIRGINIA - UV, 2003). This Protestant tradition originated simultaneously in Topeka, Kansas, and Los Angeles, California, in the first years of the 20 th century (UV, 2003). Pentecostalism found a fertile ground in countries such as Mexico and Brazil, where it first appeared in the 1910s.

In Brazil, Pentecostalism borrowed heavily from shamanistic and Umbandan traditions, incorporating faith-healing and speaking in tongues as essential elements of its rituals and discourse (BASTIAN \& CUNEEN, 1998). In that country, the religion also assumed a strongly moralistic and repressive view of society and human behavior.

Brazilians' attraction to non-Catholic, Christian denominations in general (and Protestantism in particular) is not a new phenomenon. Up to the 1960s, however, Protestantism's influence was limited to German Lutheran immigrant communities, as well as to small urban groups from Presbyterian, Methodist, and Baptist denominations (EPSTEIN, 1995). Although Pentecostalism has been present in Brazil since the 1910s, conversions did not start to make an impact in the country until the 1950s, as a growing urban working class found in churches such as the Assembly of God, a Christian fervor and enthusiasm that counterpoised a sense of alienation and dissatisfaction felt toward the traditional rituals of the Catholic Church. 
The spread of Pentecostalism and other evangelical denominations in Brazil radically altered the country's religious make-up. In the span of a century, Brazil went from an overwhelmingly Catholic country where close to 100 percent of the population was at least nominally Catholic, to a more religiously diverse land, where unofficial figures estimate that Evangelicals make up as much as 20 percent of the total population (BARRO, 1998). The 1996 official Census cut that figure in half, estimating that 10.95 percent of the Brazilian population was Evangelical, while the Assembly of God, by far the most popular Brazilian Evangelical denomination, claims a membership of more than 10 million people in Brazil-compared to their more modest 2.5 million followers in the United States (BARRO, 1996).

According to the Worldwide Evangelization Crusade (EPSTEIN, 1995), Latin America had only seven million Protestants in 1960, but by 1990, that number had reached 51 million. In Brazil, where converted Catholics make up most of the new Evangelical population, the percentage of Catholics in the country is estimated to have dwindled from 90 percent in 1980 to about 70 percent by the mid-1990s (EPSTEIN, 1995). Also using 1988 figures from the Worldwide Evangelization Crusade, Stoll (1990) noted that between 1960 and 1985, Evangelicals had multiplied by a factor of 3.6 in Brazil. If that growth rate persists, Evangelicals would make up about 57.4 percent of the Brazilian population in 2010 (p. 337).

Bastian and Cuneen (1998) wrote that Protestantism's newly-found success in Latin America was due in part to the various denominations' intense and aggressive proselytism (p. 2). Faced with competition from the strong, long-established Catholic Church, as well as from their fellow non-Catholic Christian denominations, groups such as the UCKG, the Assembly of God and other Pentecostal or neo-Pentecostal churches saw mass conversions as the only way to survive and thrive in this crowded religious marketplace.

In addition to active proselytism, Bastian and Cuneen see Pentecostals' and neo-Pentecostals' ability to acculturate and adapt as a major asset in conquering new converts in countries such as Brazil. They also pin these churches' success on an entrepreneurial savvy that uses "religious marketing and the rational management of a multinational religious organization" to mobilize and reach several million people throughout the land (p. 3). 
In summary, Bastian and Cuneen (1998) and other authors (BARRO, 1998) list several reasons for the spread of Evangelicals and Pentecostals in Brazil and other Latin American countries, among them:

- An economic globalization and transnationalization process that has also produced much faster, globalized communication technologiesas well as those churches' widespread use of telecommunication technologies for proselytizing purposes;

- Successful use of mass media, traditional marketing, and wellestablished business techniques;

- Latin American countries' shift from rural to urban societies;

- An accompanying process of "religious decentralization" in which newly-urbanized and/or economically autonomous citizens move away from traditional (and in many cases oppressive) religious leaders;

- Political and social democratization itself;

- The Catholic Church's hierarchical authoritarianism, coupled by its close association with traditional political actors.

In addition, Simões (1997) sees neo-Pentecostals' use of syncretism and Afro-Brazilian rituals as an important factor in explaining their success in converting large masses of poor and working class Brazilians. At some of the UCKG services he attended, Simões saw UCKG pastors perform exorcisms and rituals to deliver congregants from evil spirits, such as an Umbandan "pomba-gira", a female entity often associated with promiscuity (pp. 1-2).

\section{UCKG's History}

The Universal Church of the Kingdom of God was founded by Edir Macedo, a former Rio state lottery employee and relapsed Catholic, in 1977. The UCKC's first temple was a converted mortuary in Rio de Janeiro (EPSTEIN, 1995). The UCKG grew slowly but steadily throughout the 1980s, as more and more Brazilians, feeling disillusioned with and alienated from the Catholic Church, gravitated toward the UCKC's fiery preachers, with their exorcism performances, sermons filled with epic good vs. evil battles, and promises to cure diseases such as cancer and AIDS (EPSTEIN, 1995).

According to the Brazilian newsmagazine Veja, as quoted by Epstein (1995) and Simões (1997), the UCKC's membership grew by 280 percent in Brazil in the first half of the 1990s, going from 900,000 to 3.5 million members in only five years. The church has expanded to at least 70 other countries, including the United States, England, Spain, Portugal, Italy, 
and a host of Latin American countries (BUCKELY, 2001; EPSTEIN, 1995; SERBIN, 1996; SIMÕES, 1997). In the late 1990s, the UCKG had already more than 2,100 temples-many of them converted theaters and movie houses-spread throughout the world. At that time, the church claimed to have more than 7,000 pastors, as well as business interests that included radio and television stations, publishing houses, newspapers, recording studios, and banks, among others (THE ECONOMIST, 1995).

The UCKG has been embroiled in controversy since its inception. One of the most well-known controversial episodes happened in October 1995, when Sergio Von Helde, a UCKG pastor, kicked and cursed an image of Our Lady of Aparecida, the patron saint of Brazil, during a late-night religious show broadcast by TV Record, the network owned by his church. Von Helde's controversial show was re-broadcast ad nauseam by the other TV networks (especially by Rede Clobo), and caused an unprecedented backlash that threatened to engulf the country in a religious war (THE ECONOMIST, 1995).

The Von Helde episode almost overshadowed some of the other UCKG-related controversies occurring at that time, including an official investigation by the Brazilian federal police into the church's alleged financial wrongdoings, including tax evasion and association with drug traffickers (EMERGING MARKETS REPORTS, 1995). In 1992, the UCKG had already been accused and investigated for fraud, tax evasion and money laundering. That year, Edir Macedo himself was arrested and spent 12 days in jail, on charges that were later dropped. Among the accusations was the charge that Bishop Macedo had accepted a US\$ 1 million donation from the Cali drug cartel for the purchase of TV Record (SIMÕES, 1997). Macedo used his arrest to promote himself as a martyr, and blamed Rede Globo and its owner, Roberto Marinho, for the "conspiracy" that had landed him in jail.

Later on, Macedo's name was tied to one of the financial scandals that brought down Brazilian President Fernando Collor de Mello and his chief fundraiser Paulo Cesar Farias (NASCIMENTO, 1996; SERBIN, 1996; SIMÕES, 1997). It was widely reported by the Brazilian media that financial kickbacks were negotiated between Macedo and the federal government when President Collor officially transferred TV Record's broadcasting license to the church in the early 1990s (NASCIMENTO, 1996). 


\section{UCKG's Ambiguous Relationship with the Mass Media}

In his very comprehensive and well-researched book on the UCKG, Leonildo Campos (1997) noted that, since its emergence in the early 20th century, Pentecostalism has expertly taken advantage of the mass media to propagate its message. In the beginning, "free" journalistic coverage of revival churches and rituals in the United States attracted much needed attention to the then-fledging movement. The tone of the early coverage was clearly negative, and tended to characterize the new religion as a bizarre cult, using words such as "orgiastic" to describe its rituals, and portraying the raciallymixed crowds as nothing short of an aberration (CAMPOS, 1997: 179). Other authors (BLOCH-HELL, 1964; HOLLENWEGER, 1976) have observed that this free early publicity inadvertently served to promote the movement, and was even used by its leaders to stress an image of persecuted martyrs that would also serve the UCKG in Brazil.

Campos (1997) noted that the early coverage of Pentecostals was very similar in Brazil, where, starting in the 1910s, other Christian denominations used their own publications to ridicule the emergent movement. According to the author, the secular press ignored Pentecostals until the 1950s, when the movement started to gain a stronger foothold in Brazil. Again, the movement was largely characterized as contrary to the basic, historical Protestant traditions, and was compared to notorious "miracle workers" operating in São Paulo and other cities at the same time. Despite sporadic mentions in the crime pages of some secular newspapers-particularly when Pentecostal pastors were sued by former converts-Campos noted that most criticism of the movement was published in the religious press (1997:181-189).

A new surge in media coverage of Evangelicals in Brazil took place in the 1980s, which coincided with the popularization of the UCKG and other non-Catholic groups. A content analysis done by Campos (1997) of stories about the UCKG published in five of the top circulation Brazilian publications (O Globo, Jornal do Brasil, Folha de São Paulo, Jornal do Comércio and IstoÉ) in 1988-1989, showed that the most popular topic (35.4 percent) was the growth of the UCKC's financial holdings or the general issues of "faith as merchandising." The second and third most popular topics were the use of non-traditional means to proselytize (22.5 percent); and conflict with Catholicism and Afro-Brazilian religions (12.9 percent), respectively (p. 184). Throughout their history, both Pentecostals in general and the UCKG in particular have had a very ambiguous and often antagonistic relationship with the mass media. The content analysis done by Campos highlights some of the most negative aspects of this relationship. If in the beginning the UCKC 
was largely ignored by the mainstream media, as soon as the Church raised its profile, most coverage turned negative. As noted in the previous section, most of the stories and profiles done on the UCKG in the 1990s dealt with either criminal accusations or ethical and religious questions with regard to some of the Church's practices and rituals.

Several of the stories also raised political issues, such as an alleged link between the UCKG and the United States' CIA, in an attempt to undermine the widespread political influence of the Comunidades Eclesiais de Base, politically liberal religious grassroots groups sponsored by the Brazilian Catholic Church (CAMPOS, 1997). The bad publicity that started in the late1980s also had the inadvertent effect of raising the profile of the Church and putting it in the public arena in a very visible way, which, paradoxically, made it more attractive to a disenfranchised section of the population.

If all these stories, even if negative, worked collectively to put the UCKG in the public eye, none of them made the Church as visible as the mediarelated transaction that came soon after that. In late 1989 and early 1990, the UCKG bought then-ailing TV Record for an estimated US\$ 45 million. The sale of TV Record, which at the time was partially controlled by television magnate Sílvio Santos, was closely covered by the rest of the Brazilian media. Soon after the transaction was concluded, already in mid-1990, a barrage of negative press coverage raised questions regarding the tactics used by Edir Macedo and his associates to raise the necessary funds.

One of the more serious accusations raised at the time was made by Carlos Magno de Miranda, a former UCKG pastor, who accused Macedo of receiving a US\$ 1 million gift from a Colombian drug cartel. Macedo was under investigation and was even briefly jailed based on this accusation, but no evidence of wrongdoing was found. Several other investigative stories appeared in 1990 and 1991, most of them focusing on the UCKC's dubious religious and financial practices, and many of them produced and broadcast by Rede Record's direct competitors, such as TV Manchete, SBT, and Rede Globo.

Throughout the 1990s, Globo and Record often exchanged accusations, and used the public airwaves they controlled to fire off investigative pieces against each other. Rede Globo aired sporadic accusations against the UCKG and Macedo, and even produced a fictional miniseries focused on characters and story lines that resembled the group and its leaders. On the other hand, TV Record, which became Rede Record in the early 1990s, also produced stories and debate shows criticizing its main rival (CAMPOS, 1997: 189). Arguably, by airing so many stories about the UCKG, Macedo and TV Record, Rede Clobo, then the undisputed audience leader in Brazil, gave the Church 
not only ammunition for further attacks, but also kept it in the public eye and might have contributed to increasing even further its influence and raising its profile.

\section{UCKG's Use of Marketing and Mass Media}

Besides unintentionally benefiting from the avalanche of negative press it received in the 1980s and 1990s, the UCKG also expertly and intentionally used marketing techniques and the mass media to its own advantage. Virtually every academic author who has written about the UCKG (BASTIAN \& CUNEEN, 1998; CAMPOS, 1997; EPSTEIN, 1995; FAUSTO, 1997; SERBIN, 1996; SIMÕES, 1997, among others) has emphasized that the Church's growth in Brazil and other countries was due in no small part to its expert use of traditional and nontraditional advertising and promotion techniques. Penha Rocha (2001) noted that the Brazilian neo-Pentecostals' use of television as their preferred "traditional" mass medium was very much aligned with a successful formula perfected in the United States in the 1970s and 1980s (p. 3). According to her, the so-called "Electronic Church" and its successful template would include a mix of expert "infusion of commercial values and experimental theologies, with emphasis on technology, charismatic leaders (televangelists), and formats that are similar to conventional broadcasting" ( $p$. 4). Rocha also emphasized that the "Electronic Church's" success was also a product of emphasizing commercial and corporate values such as efficiency, productivity, and expansion.

A survey done by Schultze (in PENHA ROCHA, 1988) with viewers of the Christian Broadcasting Network's show "700 Club," based in the U.S., indicated that most of them were attracted to the network and its brand of revivalist Christianity because they felt the Church restored a sense of authenticity, which they said had been missing from their more traditional religious experiences. Although it is paradoxical that a mediated religious experience might carry more authenticity than a "real," face-to-face ritual, it is arguable that, for many people, religious broadcasting might provide an instantaneous, direct form of communication that mirrors the way in which they acquire most of their information and entertainment; it might also reflect the detached way in which they "interact" with most facets of their daily lives. If, as Neal Gabler would argue, "real life" has become nothing more than a movie or spectator sport, religious broadcasting's popularity would be a mere reflection of a more widespread and deep-seated phenomenon.

Campos (1997) also noted that the UCKG has taken advantage of religious marketing techniques perfected by Evangelicals in the U.S. throughout the 
20th century. In a society driven by the need to succeed, and by the idea that success is measured by clearly quantifiable values (number of temples, number of followers, amount of donations), process has overtaken product, and "successful," measurable proselytizing and conversion techniques have become much more important than the religious message itself. In this context, electronic preachers are the natural heirs to the old revivalist ministers, who moved from town to town during the 1920s and 1930s, pitching their tents wherever a receptive crowd could be found.

In fact, Campos (1997) devoted a large portion of his book on the UCKC to discuss the Church's use of both traditional and nontraditional marketing. According to him, the group not only uses the tried-and-true mass media techniques used by their American counterparts, but also a grassroots style more closely associated with small-time politicians canvassing for votes (1997: 222). The UCKG has been especially successful at establishing direct communication links with its audience, both electronically and otherwise. By listening to its audience, the Church is capable of delivering exactly the "product" and the message the audience expects to hear (1997: 222).

Moreover, by being closely attuned to its public and to the latter's needs, it is possible for the UCKC to bill itself as a "Church of Results" (CAMPOS, 1997: 229), where believers are promised miracles, answers and solutions to their very specific, mundane and immediate requests. In some ways, Rede Record simply amplified and made available a new communication channel that was based, to a large extent, on very traditional, direct interface.

Rede Record's and the UCKC's expansion and success stories are so inextricably linked that it is impossible to discuss one without referring to the other. Throughout the 1990s, there was an almost complete identification between the values guiding the network's programming (and its consolidation as a serious audience contender) and the Church's. That identification occurred both at the product and process levels:

- Rede Record became a contender by billing itself as an outsider, a populist, anti-establishment network that was not afraid of taking risks and breaking out of the mold; similarly, the UCKC owes most of its success to an anti-establishment discourse that finds the group frequently at odds with all the other major religious institutions in Brazil;

- In order to lure in more viewers, Rede Record has not been afraid to use what some have characterized as a very distasteful approach to television entertainment. "Ratinho Livre," a Jerry Springer-like nightly talk show, became an overnight success and even challenged Rede Clobo's leadership by exploiting deformed babies and physical abuse on primetime (THE LONDON TIMES, 1999); 
- Some of the UCKC's most notorious religious practices, on the other hand, include regular mass exorcism sessions and miracle cures, where believers go into trances, speak in tongues, and often have to be physically restrained by Church pastors and employees (VEJA, 1995a; VEJA, 1995b);

However, that confluence of material and spiritual values is never as clear as during the regular religious broadcasting on Rede Record. As soon as the UCKG bought the network, religious programming turned into the bread-and-butter of the organization, and the Church's followers became Record's natural built-in audience. In August of 1996, Campos (1997) found 60 hours of religious programming per week on Rede Record, compared to one hour on Rede Globo and 12 minutes on SBT, respectively the first and second largest networks (p. 281). Many of those shows are modeled after the traditional televangelism found in most U.S.-based Christian networks.

Rede Record, which had 47 affiliates throughout Brazil in 1995 (EPSTEIN, 1995), boasted an advertising income of R\$123 million in 1998, a 100 percent increase compared to 1997 (SOUTH AMERICAN BUSINESS INFORMATION, 1999). At the time, the network covered 80 percent of the country's area and reached 90 percent of its population. In the same article, Rede Record was said to have invested $\mathrm{R} \$ 100$ million during the previous four years, retaining its third place among Brazilian networks, in terms of audience.

Rede Record is not the only media company owned and used by the UCKC. The Church published a magazine, Revista Plenitude, between 1983 and 1990. By the time it folded, Plenitude had a circulation of 200,000 (CAMPOS, 1997). Another magazine, Mão Amiga (Friendly Hand), is specifically directed at promoting the Associação Beneficente Cristã, a charitable organization linked to the UCKG.

More important than the magazines is Folha Universal, the Church's weekly newspaper. In 1995, Folha Universals weekly circulation was around 756,000 on the average, much higher than any Brazilian daily newspaper. For comparative purposes, the circulation of the four top Brazilian dailies in 2001 was: Folha de São Paulo (560,000), O Globo (350,000), O Dia (250,000), and O Estado de São Paulo (242,000) (Europa World Yearbook, 2001).

Folha Universal first appeared in 1992, as a successor to Tribuna Universal. The newspaper is printed in color, and is similar typographically and in size to most Brazilian secular newspapers. Most of Folha Universals story content analyzed by Campos (1997) dealt with news about the Church and its leaders; charity-related Church activities; the UCKC's ongoing "war" against Catholicism, Spiritualism, and Afro-Brazilian religions; as well as with coverage of politicians and public officials affiliated to the Church (264). Other UCKC Brazilian media holdings included 30 radio stations, two publishing houses and a recording studio (EPSTEIN, 1995). 


\section{Attempts at Globalization}

The UCKG has been reasonably successful in its attempts to become a transnational organization. As early as 1995, the Church already had around 300 temples in 46 countries, including 22 in the United States (EPSTEIN, 1995). In its expansion efforts, the UCKG has especially targeted Latin American countries (Argentina, Mexico); other Portuguese-speaking countries (Portugal, Mozambique, Angola); South Africa; Portuguese- and Spanish-speaking immigrant communities in the United States; as well as immigrant and native communities in England, Spain, Italy, Japan and other developed countries (CAMPOS, 1997; SERBIN, 1996; SIMÕES, 1997).

In the early 2000s, the UCKG was estimated to be present in between 70 (BUCKELY, 2001) and 85 countries (RAYNER, 2002). Likewise, the Church's annual global revenues were estimated to hover around US\$ 1 billion (BUCKELY, 2001) or 700 million pounds sterling (RAYNER, 2002).

Some of the UCKC's strategies for international expansion have been very similar to the techniques that contributed to its phenomenal growth in Brazil. Those include targeting unhappy, poor, disenfranchised, urban populations; adapting its rituals and ceremonies to the local cultures and religions; buying and expertly using media channels (particularly broadcasting); and purchasing highly visible cultural landmarks, such as historic movie theaters and music venues. In Porto, Portugal, for example, the UCKG purchased the famous Coliseu Cultural Complex for US\$6.5 million (SIMÕES, 1997). In London, street demonstrations and law suits from local public officials prevented the UCKG from buying the famous Brixton Academy for US\$ 8 million, and the Church had to settle for the lesser known Rainbow Theater (SIMÕES, 1997).

The UCKC's international expansion has been met with resistance especially in European countries. In England and France, the Church is viewed by many as a religious sect or cult. In France, a Congressional report described the UCKG as "dangerous," and congressmen accused the Church of trying to control people's minds (VASAGAR \& BELLO, 2000). In England, the UCKC's activities are closely monitored, especially after the Church bought Liberty Radio in 2000 (ITALIANO, 2000). The British radio code forbids onthe-air proselytizing, and the UCKC's use of the airwaves has been nothing if not controversial (VASAGAR \& BELLO, 2000).

The English chapter of the Church was caught again in a whirlwind of controversy in early 2000, when the murder of an eight-year-old girl, Victoria (Anna) Climbie, galvanized public opinion. In one of the worst child abuse cases in British history, Victoria Climbie's adoptive parents, Marie Kouao and Carl Manning, were convicted of murder for the neglect and physical abuse 
the girl suffered in the last months of her life. Victoria's parents believed the little girl was possessed by demons, and took her to the UCKG's temple in Finsbury Park, London, four times in the last eight days of her life. During the trial of Victoria's parents, the UCKC minister who attended to the girl said he still believed she had been possessed by demons, and that the girl had "spiritual problems" (THE GUARDIAN, 2001; RAYNER, 2002).

The British government's Charity Commission, in charge of investigating concerns or accusations involving charitable organizations, started an investigation of the UCKG in April 2001. In a report published in May 2003, the Commission instructed the Church to adopt a national policy on child protection. The Commission also found that several of the UCKC's trustees, ultimately responsible for managing the organization's finances, were being paid as pastors and deacons without proper authorization. They were also instructed to resign from the Church's board, which they did in late 2002 (M2 PRESSWIRE, 2003).

In February 2000, the French branch of the UCKG bought La Scala music hall, one of Paris's oldest and most celebrated venues. Built in 1874, the building had hosted some of the most famous performers of the Belle Époque. La Scala was turned into a cinema in 1936, and had been closed for several years until it was bought by the Church (BELL, 2000). The purchase of La Scala followed a long investigation of the UCKC's activities by the French secret service. The Church was classified as a sect by the French government's report.

The UCKG is also hoping to take root among the 260,000-strong Brazilian immigrant community in Japan, eventually turning its Japanese branch into a springboard to the Asian continent. Bishop Celso Rebequi, based at the UCKC's cathedral and headquarters in Hamamatsu, told the Asahi Shimbun newspaper, "When the Universal Church started in Japan (six years ago) we had two pastors; today we have about 20 and we intend to open churches all over the continent of Asia" (ASAHI SHIMBUN, 2002). The newspaper also reported that the Church had to change its proselytizing style in Japan, where street preaching is often associated with doomsday cults such as Aum Shinrikyo.

The UCKG's expansion to the United States has also been met with resistance and controversy. After being investigated by the Brazilian tax authorities in the early 1990s, the Church's founder, Bishop Edir Macedo, took refuge in New York, where he lived for several years. After establishing itself in New York, the UCKG spread to New Jersey, Massachusetts, Rhode Island, California, Illinois, Florida, Texas, Washington, and Georgia (SEYMOUR, 2001). One of the controversies faced by the U.S. branch of the UCKG took place in 
the Houston area, where members of an immigrant family accused Church leaders of running them out of town after Jesus Lorenzo, a small business owner, publicly accused the UCKG of fraud (ZUNICA, 2000). In a widely mediapublicized polemic, Lorenzo said he was forced to give up his business and then was unable to find a job in Houston; he also accused Church members of making telephone threats and even visiting his home several times.

Eventually, the Lorenzos relocated to Kansas, but the UCKG denied any wrongdoing.

After he studied the Church's methods in Southern California, Serbin (1996) concluded that its success among poor and Latino immigrant communities in the United States followed the same formula employed in Brazil and other countries. By adapting to the culture and beliefs of its core constituency and potential flock, which in the U.S. are rooted in AfricanAmerican revivalism and Spanish-influenced Catholicism (as opposed to the Afro-Brazilian spirituality), the UCKG was able to "build an emotional bond with the congregation," which in San Diego meant a more subdued worshiping style that translated as Spanish-language singing and praising (and not so much exorcism or exalted speeches confronting other religious groups) (SERBIN, 1996). Conversely, the UCKC's success and spread among populations in cities such as London and Paris, where African immigrants make up a sizable portion of the flock, has meant incorporating some of the Animistic and spiritual beliefs that the Church fights against in places such as Brazil.

\section{BIBLIOGRAPHY}

ASAHI SHIMBUN ."Religion”. 2002, June 28

BARRO, A. C. Brazil. Christianity today, 42(13), 1998, pp. 70-72.

BASTIAN, J.-P., \& Cuneen, J. The New Religious Map of Latin America: Causes and Social Effects. Cross Currents, 48(3), 1998, pp. 330-337.

BELL, S. "Concern for Paris Theatre After Sect Moves". In. The

Scotsman, 2000, February 04, p. 17.

BRAZIL. The Europa World Year Book 2001, Vol. I. London: Europa Publications, 2000. 
BUCKLEY, S. "Prosperity Theology Pulls on Purse Strings; Promises of Riches Entice Brazil's Poor". The Washington Post, 2001, February 13, p. A16.

CHRISTIANITY TODAY. "Brazil Seeks to Freeze Leader's Assets". 40, 1996, March 05, p. 78.

EMERGING MARKETS REPORTS. "Brazil Police Investigating Evangelical Church". 1995, December 27.

EPSTEIN, J. "Evangelical Fervor Stirs Brazil". Christian Science Monitor, 1995, November 15, p. Al.

GAZETA MERCANTIL. “Rede TV! Improves Audience”. 2002, November 07.

GAZETA MERCANTIL. "Rede TV Station Struggles for Third Place". 2002, July 30

INSTITUCIONAL REDE RECORD'S OFFICIAL WEBSITE. “Conheça a História da TV com Calor Humano". Available: http://www.rederecord.com.br [2004, january 21]. (Last Updated: 2004, January 21).

ITALIANO, L. "Dodi's Dad Does a Deal With Exorcism Church". New York Post, 2000, August 06, p.23.

M2 PRESSWIRE. "Charity Commission Publishes Report on the Universal Church of the Kingdom of God". 2003, May 12.

NASCIMENTO, G. "Ação Entre Amigos”. Istoé, 1996 January 03, pp. 22-25.

RAYNER, J. "Without Prejudice: Gospel of Green". The Observer, 2002, March 03, p. 31.

ROCHA, P. "O Sucesso da Igreja Eletrônica no Brasil- rede Record e Rede Vida”. Paper Presented at the 1998 Sociedade Brasileira de Estudos Interdiciplinares da Comunicação (Intercom) National Conference. Brazil, 1998, September.

SERBIN, K. "Brazilian Church Builds an International Empire". Christian Century, 113(12), 1996, April 10, pp. 398-404.

SEYMOUR, Jr., A. "Church Raises Eyebrows on Peachtree Street; Brazilian Sect Has Faced Past Investigations". Atlanta Journal-Constitution, 2001, June 19, p.b6.

SIMÕES, P. The Igreja Universal de Reino de Dues: Syncretism of the Scared and the Secular. Unpublished Manuscript, 1997.

SOUTH AMERICAN BUSINESS INFORMATION. "Rede Record is Ranked Third in Brazil". 1999, May 10.

THE ECONOMIST. "Brazil: Holy Wars”. 1995, November 11.

THE GUARDIAN. “The Exorcists”. 2001, January 15, p. 6.

THE LONDON TIMES.“Brazil's Tacky Shows Drag TV Into Mud”. 1999, January 02, p. Al6. 
VASAGAR, J., \& BELLOS, A. "Brazilian Sect Buys London Radio Station". The Guardian, 2000, August 30, p.4.

VEJA. “Com Fé, Dinheiro e Fiéis”. 1995a, October 25, pp.96-105.

VEJA. “Sai, Satanás”. 1995b, August 09, pp. 80-82.

ZUNIGA, J.A. "Challenge of Church Costs Couple; Pair Say Threats Caused Them to Leave Houston". The Houston Chronicle, 2000, August 20, p.a37.

Raul Reis is an associate professor of journalism at California State University, Long Beach, where he teaches online journalism, research methods, global news media, and mass media theory. He has a doctorate from the University of Oregon, and worked as a professional journalist in Brazil and the United States. He has published studies on the Brazilian television and cable industries; on the rise of Pentecostal religions in Brazil and their media connections; on the impact of mass media on traditional cultures; and on environmental and science journalism. 